\title{
Pengaruh Kompetensi Dan Pengembangan Karier Terhadap Kinerja Pegawai Pada Dinas Perkebunan Kabupaten Way Kanan
}

\author{
Nur aeni ${ }^{(1)^{*}}$, Arifin $^{(2)}$ \\ ${ }^{(1)}$ Universitas Sang Bumi Ruwa Jurai \\ *email nuraeniharyo@gmail.com
}

\begin{abstract}
Abstrak.
Penelitian ini bertujuan untuk mengetahui pengaruh kompetensi dan pengembangan Karier terhadap Kinerja Pegawai pada Dinas Perkebunan Kabupaten Way Kanan. Penelitian ini di lakukan pada dinas perkebunan kabupaten Way kanan. Jenis penelitian yang digunakan pada penelitian ini adalah jenis penelitian kuantitatif deskriptif dengan teknik analisis data menggunakan regresi linear berganda.Sampel yang digunakan dalam penelitian ini adalah sebanyak 25 orang pegawai pada Dinas Perkebunan Kabupaten Way Kanan. Sumber data yang digunakan dalam penelitian ini menggunakan data primer dan data skunder. Tekik pengumpulan data yang digunakan menggunakan wawancara, angket dan observasi. Validasi menggunakan korelasi produc moment, dan reablitas menggunakan alpha cronbach. Berdasarkan hasil penelitian yang dilakukan menunjukan bahwa besarnya pengaruh kompetensi dan pengembangan karir terhadap kinerja pegawai di Dinas Perkebunan Kabupaten Way Kanan sebesar 53,4\% dan sisanya 46,6\% dipengaruhi oleh faktor lain. Dengan demikian disimpulkan bahwa terdapat pengaruh kompetensi dan pengembangan karier terhadap kinerja pegawai pada dinas perkebunan kabupaten Way Kanan.
\end{abstract}

Kata kunci: Kompetensi, Pengembangan Karier, Kinerja Pegawai

\section{Abstract.}

This study aims to determine the effect of competence and career development on employee performance at the Way Kanan district plantation office. The research was carried out at the Way Kanan district plantation office The type of research used in this research is descriptive quantitative research with data analysis techniques using multiple linear regression. The sample used in this study were 25 employees at the Plantation Office of Way Kanan Regency. Sources of data used in this study use primary data and secondary data. Technique the data used using interviews, questionnaires and observations. Validation uses the use of product moments, and reliability uses Cronbach's alpha. Based on the results of research which shows that a strong influence and career development on the performance of employees at the Plantation Office of Way Kanan Regency is 53.4\% and the remaining $46.6 \%$ is influenced by other factors. Thus it is set aside that there is influence and career development on employee performance at the Way Kanan district plantation office.

Keywords: Competence, Career Development, Employee Performance

\section{PENDAHULUAN}

Sumber daya manusia merupakan salah satu sumber daya yang dan paling penting dalam sebuah organisasi, manusia merupakan unsur dasar yang dapat melaksanakan pekerjaan, oleh karena itu sudah sewajarnya bila pihak manajemen harus memberikan perhatian lebih melalui kebijakan-kebijakan yang diambil. Saat ini banyak masalah yang timbul berkaitan dengan ketenagakerjaan terutama kinerja pegawai. Untuk itu organisasi akan berkembang dan mampu bertahan dalam lingkungan persaingan yang kompetitif apabila didukung oleh pegawai-pegawai yang kompeten. Hal tersebut menunjukkan bahwa konsep kinerja dan kompetensi menjadi hal yang penting dan menarik untuk dikaji. 
Menurut Spencer dan Spencer dalam yaang dikutip (Pramularso 2018) kompetensi adalah karakteristik yang mendasari seseorang berkaitan dengan efektivitas kinerja individu dalam pekerjaannya atau karakteristik dasar individu yang memiliki hubungan kausal atau sebagai sebab-akibat dengan kriteria yang dijadikan acuan, efektif atau berkinerja prima atau superior di tempat kerja atau pada situasi tertentu. Artinya kompetensi merupakan suatu hal yang mendasar tentantang pengetahuan keterampilan dan kualitas individ oleh sebabnya hal tersebut perlu dikembangkan.

Pengembangan kemampuan kerja pegawai berbasis kompetensi dan uraian tugas (Joni 2020) merupakan salah satu upaya dapat meningkatkan kinerja, karena pengembangan pegawai berbasis kompetensi dan uraian tugas merupakan wujud perhatian dan pengakuan organisasi atau pimpinan kepada pegawai yang menunjukan kemampuan kerja, kerajinan, dan kepatuhan serta disiplin kerja

Pengembangan karier(Dharmawan 2018) adalah satu langkah untuk menciptakan karakter seorang pegawai yang dibutuhkan oleh perusahaan dalam usahanya untuk mencapai target-targetnya.

Fenomena yang ada pada pegawai Dinas Perkebunan Kabupaten Way Kanan, antara lain rendahnya kompetensi pegawai dari tingkat pendidikan dan kurangnya pengetahuan teknologi yang mengakibatkan pekerjaan yang ada sering mengalami kendala dalam penyusunan perencanaan, pelaporan dan pengaksesan data. Hal ini terjadi karena banyak pegawai yang tidak menguasai substansi pekerjaan dan tidak dapat mengoperasikan komputer, sehingga tugas-tugas hanya ditangani oleh beberapa pegawai saja. Dari 26 orang Pegawai Negeri Sipil (PNS) hanya 10 orang yang dapat mengoprasikan komputer/ laptop sedangkan 16 PNS belum dapat mengoperasikan komputer.

Selain itu masih adanya pegawai dengan kompetensi yang tidak saling mendukung antara pendidikan yang dimiliki, pengalaman kerja, dan pelatihan. Contoh jabatan teknis yang kompetensi yang dipersyaratkan pendidikan khusus mengenai perkebunan tetapi dijabat oleh seseorang dari jurusan lain.

Faktor yang dapat mempengaruhi kinerja pegawai selain kompetensi, adalah pengembangan karier. Ditinjau dari perspektif organisasi, kegagalan memotivasi pegawai untuk merencanakan karier mereka akan berakibat pada turunnya komitmen, sehingga dapat mengakibatkan pegawai frustasi, merasa tidak dihargai, merasa tidak bernilai, dan mempercepat keinginan untuk berpindah organisasi. Organisasi harus mengelola karier pegawai untuk memaksimalkan pengembangan karier mereka. Pengembangan karier yang efektif tentuny

Mondy dalam Nawawi (2013: 24) menyatakan bahwa pengembangan karier adalah pendekatan formal yang digunakan organisasi untuk memastikan bahwa orang dengan kualifikasi dan pengalaman yang tepat tersedia jika dibutuhkan. Pengembangan karier formal berperan penting untuk memelihara angkatan kerja yang termotivasi kerja dan berkomitmen.

Menurut Josiah yang dikutip(Nelson 2020) oleh menunjukan dalam kinerja terkandung pengertian kemampuan kerja atau prestai kerja

Berdasarkan penelitian sebelumnya oleh (Joni 2020) menunjukan Kompetensi SDM dan Uraian tugas berpengaruh positif terhadap Kinerja. Dalam penelitian ini samasama meneliti tentang kompetensi terhadap kinerja dan peneliti ingin meneliti tentang pengembangan kariernya.

Penelitian selanjutnya oleh (Supardi 2016) bahw dengan adanya pengembangan karir dan dilaksanakan dengan baik, maka setiap pegawai akan berupaya untuk mencapai kinerja yang sebaik-baiknya, sehingga pada gilirannya akan mempunyai 
kesempatan untuk mengembangkan karirnya yang pada akhirnya cepat atau lambat akan sangat mendukung dalam proses pencapaian tujuan organisasi secara berdaya guna dan berhasil guna. Oleh karena itu, secara keseluruhan bahwa pengembangan karir baik langsung maupun tidak langsung berhubungan dengan peningkatan kinerja seorang pegawai.

Penelitian lain (Prativi, Dewi, and Chairia 2020) menunjukan bahwa pengembangan karier berpengaruh positif dan signifikan terhadap kinerja karyawan Kantor Pusat PT. Pos Indonesia (Persero) Bandung

Kinerja dalam organisasi merupakan aspek penting untuk mengetahui berhasil atau tidaknya tujuan organisasi yang telah ditetapkan, dimana kinerja merupakan kombinasi dari kemampuan, usaha dan kesempatan yang dinilai dari hasil kerjanya, yang dicapai seseorang dalam melaksankan tugas-tugas yang dibebankan. Dengan demikian isu tentang kompetensi, pengembangan karier dan kinerja pegawai menjadi hal yang penting dan menarik dalam upaya pengelolaan sumber daya manusia dalam sebuah organisasi.

Berdasarkan uraian diatas, maka penulis tertarik untuk mengambil judul penelitian "PENGARUH KOMPETENSI DAN PENGEMBANGAN KARIER TERHADAP KINERJA PEGAWAI PADA DINAS PERKEBUNAN KABUPATEN WAY KANAN".

\section{METODE PENELITIAN}

Objek penelitian adalah permasalahan di kompetensi, pengembangan karier dan kinerja pegawai pada Dinas Perkebunan Kabupaten Way Kanan. Sampel yang digunakan dalam penelitian ini adalah sebanyak 25 orang.

Jenis dan sumber data yang digunakan menggunakan data primer dan data skunder. Metode pengumpulan data menggunakan wawancara, observasi, dan kuisioner.
Uji validitas dalam penelitian ini menggunakan korelasi product moment dan uji reablitas menggunakan alpha cronbach.

Uji analisis data menggunakan regresi linear berganda dengan persamaan sebagai berikut :

$$
Y=\alpha+b 1 \times 1+b 2 \times 2+E t
$$

$\mathrm{Y}=$ Kinerja

$\alpha=$ Parameter

$\beta 1=$ Koefisien Regresi

$\beta 2=$ Koefisien Regresi

$\mathrm{X}_{1}=$ Kompetensi

$\mathrm{X}_{2}=$ Pengembangan Karier

$\mathrm{Et}=$ Error term

(Sugiyono 2013)

Uji Hipotesis Penelitian menggunakan uji t dan uji $\mathrm{f}$

\section{HASIL DAN PEMBAHASAN}

Berdasarkan hasil penelitian tentang pengaruh kompetensi dan pengembangan karier

\section{Uji Validitas}

Suatu skala validitas disebut valid bila ia melakukan apa yang seharusnya dilakukan dan mengukur apa yang seharusnya diukur. Dengan kata lain validitas ini adalah sebuah fungsi yang menunjukkan seberapa baik dimensi dan elemen sebuah variabel dengan indikator indikatornya telah diukur. Pengujian validitas instrumen pertanyaan menggunakan 10 (sepuluh) sampel uji coba soal pertanyaan setiap variabelnya.

Hasil perhitungan menggunakan diperoleh hasil nilai korelasi product moment sebagai berikut :

\section{a. Kompetensi $\left(\mathrm{X}_{1}\right)$}

Hasil perhitungan menunjukan bahwa seluruh indikator untuk variabel Kompetensi adalah lebih besar dari $r$ table, sehingga seluruh indikator dinyatakan valid. 


\section{b. Pengembangan Karier (X2)}

Hasil perhitungan menunjukan bahwa nilai $r$ hitung lebih besar daripada $r$ tabel hal ini menunjukkan bahwa seluruh item soal pada variable pengembangan karier dinyatakan valid.

\section{c. Kinerja Pegawai}

Hasil perhitungan menunjukan nilai $r$ hitung lebih besar daripada $r$ tabel hal ini menunjukkan bahwa seluruh item soal pada variabel kinerja pegawai dinyatakan valid.

Dengan demikian indikator kompetensi, pengembangan karier dan kinerja pegawai dinyatakan valid.

\section{Uji Reabilitas}

Hasil perhitungan dengan menggunakan crochbach alpha menunjukan bahwa nilai crochbach alpha lebih besar dari 0.600 dengan demikian data dinyatakan reliabel.

\section{Uji Regresi Linier Berganda}

\section{Tabel 1. Uji Regresi linear berganda}

\begin{tabular}{|c|c|c|c|c|c|c|}
\hline \multicolumn{7}{|c|}{ Coefficients $^{a}$} \\
\hline \multirow{2}{*}{\multicolumn{2}{|c|}{ Model }} & \multicolumn{2}{|c|}{$\begin{array}{l}\text { Unstandardize } \\
\text { d Coefficients }\end{array}$} & \multirow[t]{2}{*}{$\begin{array}{c}\text { Stand } \\
\text { ardize } \\
d \\
\text { Coeffi } \\
\text { cients } \\
\text { Beta }\end{array}$} & \multirow[t]{2}{*}{$\mathrm{t}$} & \multirow[t]{2}{*}{ Sig. } \\
\hline & & B & $\begin{array}{l}\text { Std. } \\
\text { Error }\end{array}$ & & & \\
\hline 1 & (Constant) & $\begin{array}{r}2.03 \\
6\end{array}$ & $\begin{array}{r}1.28 \\
4\end{array}$ & & $\begin{array}{l}1.5 \\
85\end{array}$ & $\begin{array}{r}.12 \\
7\end{array}$ \\
\hline & KOMPETE & .612 & .126 & .656 & 4.8 & .00 \\
\hline & $\begin{array}{l}\text { NSI } \\
\text { PENGEMB }\end{array}$ & 322 & 129 & .337 & $\begin{array}{r}04 \\
2.5\end{array}$ & .02 \\
\hline & $\begin{array}{l}\text { ANGAN_K } \\
\text { ARIER }\end{array}$ & & & & 01 & 0 \\
\hline & a. Deper & nor & able & INER & & \\
\hline
\end{tabular}

Berdasarkan hasil perhitungan dan output pengolahan data SPSS v.21, maka persamaan regresi yang di bentuk sebagai berikut :

$$
Y=a+b_{1} X_{1}+b_{2} X_{2}+e t
$$

$$
Y=2,036+0,612 X_{1}+0,322 X_{2}+e t
$$

\section{Interpretasi:}

Berdasarkan persamaan regresi linear seperti diatas, maka dapat diberikan interpretasi sebagai berikut:

a. Nilai konstanta (a) sebesar 2,036, menunjukkan nilai konstanta yang positif artinya apabila kompetensi dan pengembangan karier tidak berubah maka kinerja pegawai akan tetap memiliki nilai 2,036 Nilai Koefisien regresi $X_{1}$ sebesar 0,612, mengandung arti jika kompetensi ditingkatkan 1 satuan maka akan meningkatkan kinerja pegawai sebesar 0,612 satuan dengan asumsi variabel lain tetap.

b. Koefisien regresi $X_{2}$ sebesar 0,322, mengandung arti jika pengembangan karier ditingkatkan 1 satuan maka akan meningkatkan kinerja pegawai sebesar 0,322 satuan dengan asumsi variabel lain tetap.

Dari keterangan diatas dapat ditarik kesimpulan bahwa nilai koefisien regresi $\mathrm{X}_{1}$ lebih besar dari pada nilai koefisien regresi $\mathrm{X}_{2}$, hal ini menunjukkan bahwa kontribusi variabel kompetensi lebih tinggi atau dominan dibandingkan variabel pengembangan karier dalam meningkatkan kinerja pegawai pada Dinas Perkebunan Kabupaten Way Kanan.

\section{Uji Hipotesis}

\section{Uji T}

Berdasarkan hasil penelitian bahwa kompetensi dan pengembangan karir terhadap kinerja pegawai hasil perhitungan menunjukan bahwa thitung lebih besar dari $\mathrm{t}$ tabel dengan demikian terdapat pengaruh kompetensi dan pengembangan terhadap kinerja pegawai.

\section{Uji F}

Pengujian pengaruh variabel bebas kompetensi (X1), pengembangan karier (X2) secara simultan terhadap kinerja 
pegawai (Y) pada Dinas Perkebunan Kabupaten Way Kanan, menggunakan uji-F dengan tingkat kepercayaan 95 persen $(\alpha=$ $0,05)$ dan derajat kekebasan untuk pembilang $\mathrm{k}-1=3-1=2$, serta derajat kebebasan untuk penyebut $n-k=25-3=22$

\begin{tabular}{|c|c|c|c|c|c|}
\hline \multicolumn{6}{|c|}{ ANOVA $^{b}$} \\
\hline Model & $\begin{array}{c}\text { Sum of } \\
\text { Square } \\
\text { s }\end{array}$ & Df & $\begin{array}{l}\text { Mean } \\
\text { Square }\end{array}$ & $\mathrm{F}$ & Sig. \\
\hline $\begin{array}{l}1 \text { Regres } \\
\text { sion }\end{array}$ & 993.766 & 2 & $\begin{array}{r}496.88 \\
3\end{array}$ & $\begin{array}{r}373 . \\
422\end{array}$ & $\begin{array}{r}.00 \\
0^{\mathrm{a}}\end{array}$ \\
\hline $\begin{array}{l}\text { Residu } \\
\text { al }\end{array}$ & 29.274 & 22 & 1.331 & & \\
\hline Total & 1023.040 & 24 & & & \\
\hline \multicolumn{6}{|c|}{$\begin{array}{l}\text { a. Predictors: (Constant), } \\
\text { PENGEMBANGAN_KARIER, KOMPETENSI } \\
\text { b. Dependent Variable: KINERJA }\end{array}$} \\
\hline
\end{tabular}

Dari uji-F atau pengujian secara simultan/keseluruhan, diperoleh hasil dari 2 (dua) variabel bebas yang terdiri dari $X_{1}$ dan $\mathrm{X}_{2}$ tersebut nilai $F_{\text {hitung }}$ sebesar 373,422 . Sedangkan nilai $F_{\text {tabel }}$ dengan dk pembilang $=2$ dan $\mathrm{dk}$ penyebut $\mathrm{n}-\mathrm{k}=25-3=22$, tingkat kepercayaan $95 \%(\alpha=0,05)$ diperoleh nilai $\mathrm{F}_{\text {tabel }}=3.44$.

Hasil perhitungan dengan satu arah yang menggunakan tingkat kepercayaan 95\% $(\alpha=0,05)$, derajat kebebasan untuk pembilang $\left(\mathrm{df}_{1}\right)=2$, dan derajat kebebasan untuk pembagi $\left(\mathrm{df}_{2}\right)=22$ diperoleh nilai $F_{\text {hitung adalah 373,422 lebih besar }}$ dibandingkan dengan nilai $F_{\text {tabel }}$ sebesar 3,44 , serta hasil uji signifikansi menunjukkan nilai Sig hitung sebesar 0,000 lebih kecil dari 0,05, maka disimpulkan Ho di tolak dan $\mathrm{H}_{\mathrm{a}}$ "di terima”. Dengan demikian kompetensi $\left(\mathrm{X}_{1}\right)$ dan pengembangan karier $\left(\mathrm{X}_{2}\right)$ secara bersama-sama atau simultan berpengaruh positif dan signifikan terhadap kinerja pegawai pada Dinas Perkebunan Kabupaten Way Kanan.

\section{Uji Koefisien Determinasi $\left(\mathbf{r}^{2}\right)$}

Koefisien determinasi $(\mathrm{KD})=\mathrm{R}$. Square $=$ $0.731 \times 0.731=0,534$.

$0,534 \times 100 \%=53,4 \%$ jadi dapat ditarik kesimpulan bahwa besarnya pengaruh kompetensi dan pengembangan karier terhadap kinerja pegawai pada Dinas Perkebunan Kabupaten Way Kanan sebesar $53,4 \%$ dan sisanya $46,6 \%$ dipengaruhi oleh faktor lain yang tidak penulis teliti seperti, motivasi kerja, lingkungan kerja, pendidikan, pelatihan kerja, budaya organisasi dan lain-lainnya.

\section{Pembahasan}

\section{Pengaruh Kompetensi terhadap kinerja pegawai pada Dinas Perkebunan Kabupaten Way Kanan}

Berdasarkan hasil penelitian yang dilakukan oleh peneliti terhadap pegawai di Kantor Dinas Perkebunan Kabupaten Way Kanan terdapat hasil yakni terdapat pengaruh variabel kompetensi terhadap kinerja pegawai pada Dinas Perkebunan Kabupaten Way Kanan. Bahwa kompetensi merupakan salah satu indikator yang wajib dimiliki seorang pegawai dalam melaksanakan pekerjaannya. Pegawai yang memiliki kompetensi yang baik akan berdampak pada kualitas kinerja yang juga akan baik, namun sebaliknya jika kompetensi pegawai yang ada di suatu instansi tidak maksimal maka akan berdampak pada kualitas kinerja pegawai tersebut yang tidak maksimal yang dapat mengakibatkan suatu instansi tidak mencapai target kinerja yang sudah ditentukan.

Menurut Sedarmayati (Sedarmayanti 2017) kompetensi mencakup berbagai faktor teknis dan non teknis, kepribadian dan tingkah laku, soft skills dan hard skills, kemudian dipergunakan sebagai aspek yang dinilai banyak perusahaan untuk merekrut karyawan ke dalam organisasi. Pelaku bisnis maupun organisasi bisnis akan lebih selektif dalam merekrut karyawan dengan dimasukkannya kompetensi sebagai variabel dalam proses seleksi.

Dari hasil penelitian terdapat fakta bahwa berdasarkan dari hasil analisa bahwa parameter yang harus ditingkatkan adalah mengenai tingkat pengetahuan pegawai 
terhadap tugas yang diembannya, hal ini terkait dari kemampuan pegawai untuk mengoperasikan komputer, bahwa masih banyak pegawai yang belum bisa menggunakan komputer sehingga tugas yang dikerjakan menjadi terhambat dalam penyelesaiannya, kemudian masih adanya penempatan pegawai yang tidak sesuai dengan keilmuannya dan juga penguasaan terhadap tugas dan fungsi bidang yang diembannya hal ini terkait dari pendidikan formal pegawai yang tidak sesuai dengan jabatan yang diemban kemudian adanya rolling pegawai dari dinas lainnya sehingga penguasaan tugas dan fungsi belum maksimal dari pejabat yang masih baru dipromosikan pada Dinas Perkebunan Kabupaten Way Kanan, berdasarkan hal tersebut perlu adanya peningkatan kompetensi pegawai yang ada saat ini guna mendukung pencapaian target kinerja yang adaBerdasarkan hasil uji kuantitatif didapat hasil yakni berdasarkan uji $\mathrm{t}$ atau $\mathrm{t}$ tes didapat $\mathrm{t}$ hitung sebesar 4.864 lebih besar dari $t$ tabel 2.073 yakni dengan tingkat signifikan sebesar 0,000. Karena probability jauh lebih kecil dari 0,05 maka kompetensi berpengaruh terhadap kinerja. Maka $\mathrm{H}_{0}$ ditolak dan Ha diterima. Dengan demikian hipotesis: "Ada pengaruh kompetensi terhadap kinerja pegawai pada Dinas Perkebunan Kabupaten Way Kanan" diterima.

\section{Pengaruh Pengembangan Karier terhadap kinerja pegawai pada Dinas Perkebunan Kabupaten Way Kanan}

Berdasarkan hasil penelitian yang dilakukan peneliti bahwa terdapat pengaruh pengembangan karier terhadap kinerja pegawai pada Dinas Perkebunan Kabupaten Way Kanan, bahwa jika pengembangan karier dilaksanakan dengan baik dan konsisten maka akan berdampak pada semangat kerja pegawai sehingga pegawai akan termotivasi untuk melakukan yang terbaik bagi organisasinya dalam hal ini Dinas perkebunan Kabupaten Way Kanan,
Pengembangan karir menurut Mondy yang dikutip (Parimita, Wahda, and Handaru 2015) "Pengembangan karir adalah pendekatan formal yang digunakan perusahaan untuk memastikan bahwa 334 Widya Parimita \& Laysa Aneu Afrilla Wahda orang-orang dengan kualifikasi dan pengalaman yang tepat, tersedia saat dibutuhkan. Pengembangan karier formal berperan penting untuk memelihara angkatan kerja yang termotivasi kerja dan berkomitmen. Perencanaan dan pengembangan karier menguntungkan individu maupun organisasi dan dengan demikian harus dipertimbangkan secara berhati-hati oleh keduanya. Dari pengertian pengembangan karier di atas, pegawai dan organisasi mempunyai peran masing-masing dalam usaha pengembangan karier. Pegawai mempunyai. tugas berupa perencanaan karier dan organisasi mempunya tugas memberikan bantuan berupa programprogram pengembangan karier, agar pegawai yang potensial dapat mencapai setiap jenjang karier sejalan dengan usaha mewujudkan perencanaan kariernya.

Terkait pengembangan karier fenomena yang terjadi selama ini menunjukkan masih adanya berbagai persoalan dalam pengembangan karier PNS. Meskipun perarturan perundang-undangan sudah secara jelas menetapkan dasar pengembangan karier PNS harus berdasarkan kualifikasi, kompetensi kinerja serta mempertimbangkan aspek integritas dan moralitas namun dalam implementasinya masih sering tidak sesuai dari ketentuan peraturan yang berlaku. Dari hasil pengamatan khususnya di Dinas Perkebunan Kabupaten Way Kanan, ada indikasi belum optimalnya pelaksanaan pengembangan karier pegawai. Dalam pengisian promosi jabatan kurang memberikan kesempatan kepada pegawai yang ada. Di dalam pengisian / promosi jabatan banyak berasal dari dinas atau instansi lain. Akibatnya ada pegawai yang perkembangan kariernya berjalan lambat 
bahkan ada yang tidak jalan. Masalah lain adanya pegawai yang belum menunjukkan tanggung jawabnya dalam melaksanakan tugas dan tidak tepat waktu dalam penyelesaian pekerjaan. Masalah-masalah yang timbul dalam proses kerja diatas pada akhirnya mempengaruhi tingkat pencapaian kinerja pegawai dalam menjalankan tugas dan fungsinya.

Berdasarkan hal tersebut perlu adanya perhatian yang serius bagi pemangku kebijakan untuk memperhatikan pengembangan karier pegawai, karena pengembangan karier yang dilakukan dengan baik dan konsisten maka akan menambah semangat kerja pegawai dan berdampak positif bagi kinerjanya sehingga meningkatkan capaian kinerja organisasi dalam hal ini Dinas Perkebunan Kabupaten Way Kanan.

Berdasarkan hasil uji kuantitatif di dapat hasil yakni dari uji t atau tes didapat t hitung sebesar 2,501 lebih besar dari t tabel 2.073 yakni dengan tingkat signifikan sebesar 0,020. Karena probability jauh lebih kecil dari 0,05 maka pengembangan karier berpengaruh terhadap kinerja. Maka $\mathrm{H}_{0}$ ditolak dan Ha diterima. Dengan demikian hipotesis: "Ada pengaruh pengembangan karier terhadap kinerja pegawai pada Dinas Perkebunan Kabupaten Way Kanan" diterima.

Dari uji-F atau pengujian secara simultan/keseluruhan, diperoleh hasil dari 2 (dua) variabel bebas yang terdiri dari $\mathrm{X}_{1}$ danX $X_{2}$ tersebut nilai $F_{\text {hitung }}$ sebesar373,422. Sedangkan nilai $F_{\text {tabel }}$ dengan dk pembilang $=2$ dan $\mathrm{dk}$ penyebut $\mathrm{n}-\mathrm{k}=25-3=22$, tingkat kepercayaan $95 \%(\alpha=0,05)$ diperoleh nilai $\mathrm{F}_{\text {tabel }}=3.44$.

Hasil perhitungan dengan satu arah yang menggunakan tingkat kepercayaan 95\% $(\alpha=0,05)$, derajat kebebasan untuk pembilang $\left(\mathrm{df}_{1}\right)=2$, dan derajat kebebasan untuk pembagi $\left(\mathrm{df}_{2}\right)=22$ diperoleh nilai Fhitung adalah 373,422 lebih besar dibandingkan dengan nilai $F_{\text {tabel }}$ sebesar
3,44, serta hasil uji signifikansi menunjukkan nilai Sig hitung sebesar 0,000 lebih kecil dari 0,05, maka disimpulkan Ho di tolak dan $\mathrm{H}_{\mathrm{a}}$ "di terima. Dengan demikian kompetensi $\left(\mathrm{X}_{1}\right)$ dan pengembangan karier $\left(\mathrm{X}_{2}\right)$ secara bersama-sama atau simultan berpengaruh positif dan signifikan terhadap kinerja pegawai pada Dinas Perkebunan Kabupaten Way Kanan.

\section{KESIMPULAN}

Berdasarkan penelitian yang dilakukan menunjukan hasil uji kuantitatif di dapat hasil yakni dari uji t atau t tes didapat t hitung sebesar 2,501 lebih besar dari t tabel 2.073 yakni dengan tingkat signifikan sebesar 0,020. Karena probability jauh lebih kecil dari 0,05 maka pengembangan karier berpengaruh terhadap kinerja bahwa adanya pengaruh kompetensi dan pengembangan karier terhadap kinerja pegawai.

\section{DAFTAR PUSTAKA}

Dharmawan. 2018. "PENGARUH KEPEMIMPINAN DAN MOTIVASI KERJA TERHADAP KEPUASAN KERJA PADA BADAN PENGELOLAAN KEUANGAN DAN ASET DAERAH KABUPATEN PESISIR BARAT." Jurnal Ilmu Manajemen Saburai 4(2):49-58.

Joni, Rafian. 2020. "PENGARUH KOMPETENSI SUMBER DAYA MANUSIA DAN URAIAN TUGAS TERHADAP KINERJA PEGAWAI PADA BADAN PENDAPATAN DAERAH KABUPATEN PESISIR BARAT." Jurnal Ilmu Manajemen Saburai 6(1):29-36.

Nelson. 2020. "Pengaruh Efektifitas Kerja Terhadap Kinerja Jaminan Sosial Bandar Lampung." Ekonomi, Keuangan Dan Bisnis 5:29-36. 


\section{EKOMBIS Sains}

Parimita, Widya, Laysa Aneu Afrilla Wahda, and Agung Wahyu Handaru. 2015. "Pengaruh Pengembangan Karir Dan Motivasi Terhadap Kepuasan Kerja Karyawan Pt Pos Indonesia (Persero) Bekasi." JRMSI - Jurnal Riset Manajemen Sains Indonesia 6(1):326-50. doi: 10.21009/jrmsi.006.1.01.

Pramularso, Eigis Yani. 2018. "Pengaruh Kompetensi Terhadap Kinerja Karyawan CV Inaura Anugerah Jakarta." Jurnal Widya Cipta 2(1):40-46.

Prativi, Yulinda Putri, Divina Mahardika Dewi, and Chairia. 2020. "Pengaruh Pengembangan Karier Terhadap Kinerja Karyawan Kantor Pusat PT.
Pos Indonesia (Persero) Bandung." Jimea 4(1):106-13.

Sedarmayanti. 2017. Perencanaan Dan Pengembangan SDM Untuk Meningkatkan Kompetensi, Kinerja Dan Produktivitas Kerja. Bandung: PT Refika Aditama.

Sugiyono. 2013. Metode Penelitian Kuantitatif, Kualitatif Dan $R \& D$. Bandung: Alfabeta.

Supardi, Endang. 2016. "Pengembangan Karir Kontribusinya Terhadap Kinerja Pegawai." Jurnal Geografi Gea 9(1). doi: 10.17509/gea.v9i1.1680. 